\title{
Impact of Financial and Non-Financial Voluntary Disclosure on Stock Liquidity for Jordanian Industrial Shareholding Companies Listed on Amman Stock Exchange
}

\author{
Ziad Abdul Halim AlTheibeh ${ }^{1}$, Oday Abdulraheem Alhyari ${ }^{1} \&$ Mohyedin Hamza $^{1}$ \\ ${ }^{1}$ Zarqa University, Jordan \\ Correspondence: Ziad Abdul Halim AlTheibeh, Zarqa University, Jordan. E-mail: Zyadhalabi65@yahoo.com
}

Received: September 10, 2018

Accepted: November 6, 2018

Online Published: November 13, 2018

doi:10.5539/ijbm.v13n12p125

URL: https://doi.org/10.5539/ijbm.v13n12p125

\begin{abstract}
This study aims to identify the impact of financial and non-financial voluntary disclosure on stock liquidity for Jordanian industrial shareholding companies listed on Amman Stock Exchange. For achieving this objective, the study adopted analytical methodology, as it is proper for the nature of this study. The study population consists of 60 Jordanian industrial shareholding companies listed on Amman Stock Exchange, whereas the study sample consists of 30 companies. The researchers used the appropriate statistical methods through SPSS program.

The most important results of this study that the level of voluntary disclosure on stock liquidity for Jordanian industrial shareholding companies listed on Amman Stock Exchange is medium. In addition, the results show that voluntary disclosure (financial and non-financial) does not affect on stock liquidity for Jordanian industrial shareholding companies listed on Amman Stock Exchange.

The study concluded with a set of recommendations, most important: to guide investors to the information contained in financial reports to help them make their wise investment decisions by focusing their attention on all items listed on financial reports and not focusing on certain indicators only. The information contained in financial reports would reflect a clear picture of about the status of the organization and work to raise the level of disclosure of the information contained in the financial reports through the combined efforts of the joint stock companies, auditors and Securities Commission.
\end{abstract}

Keywords: stock liquidity, voluntary financial and non-financial disclosure

\section{The General Framework of the Study}

\subsection{Introduction}

With the advent of joint stock companies and the emergence of globalization. Given the importance of disclosure of information in the performance of companies and its impact on their future and current situations, where information becomes the most important in this age, and it is the core of competition at all levels and frameworks.

In view of the importance of disclosure, companies have not only made obligatory disclosures that are required by law to be published, but also made them voluntary for both financial and non-financial, to provide a broader and more comprehensive picture for all parties to benefit from. The researchers state that this study will give a broader and more complete understanding of voluntary disclosure and stock liquidity concepts.

Consequently, that is the origin of the idea of this study, which is to find out the impact of voluntary accounting disclosure on stock liquidity in industrial sector in Amman Stock Exchange and the importance of each.

\subsection{Study Problem and Its Questions}

The study problem can be viewed through the following major question:

Is there an impact of voluntary accounting disclosure on stock liquidity for Jordanian industrial shareholding companies listed on Amman Stock Exchange?

\subsection{The Following Sub-Questions Arise from This Question}

1- Is there an impact of financial voluntary disclosure on stock liquidity for Jordanian industrial shareholding 
companies listed on Amman Stock Exchange?

2- Is there an impact of non- financial voluntary accounting disclosure on stock liquidity for Jordanian industrial shareholding companies listed on Amman Stock Exchange?

\subsection{Study Hypotheses}

This stud y seeks to know the impact of accounting disclosure on stock liquidity for Jordanian industrial shareholding companies listed on Amman Stock Exchange. Thus, the main null hypothesis was as follows:

H0: There is no statistically significant impact of accounting disclosure on stock liquidity for Jordanian industrial shareholding companies listed on Amman Stock Exchange at significance level $(\alpha \leq 0.05)$.

The major hypothesis has the following sub-hypotheses:

H01: There is no statistically significant impact of financial voluntary disclosure on stock liquidity for Jordanian industrial shareholding companies listed on Amman Stock Exchange at significance level( $(\alpha 0.05)$.

H02: There is no statistically significant impact of non-financial voluntary disclosure on stock liquidity for Jordanian industrial shareholding companies listed on Amman Stock Exchange at significance level $\left(\begin{array}{l}\alpha \\ 0.05\end{array}\right)$.

\subsection{Study Objectives}

This study attempts to draw attention to the voluntary disclosure, show its importance and its impact on stock liquidity for Jordanian industrial shareholding companies listed on Amman Stock Exchange. This can be summarized as follows:

- Recognizing financial voluntary disclosure on stock liquidity for Jordanian industrial shareholding companies listed on Amman Stock Exchange.

- Recognizing non-financial voluntary disclosure concept, which is reflected on Jordanian environment, especially in industrial sector.

- Recognizing stock liquidity and methods of its measurement.

- Understanding the concepts of financial and non-financial voluntary disclosure.

\subsection{Study Significance}

The researchers believe that this study will be important from a scientific and practical point of view and it will make a contribution and an important scientific addition, through:

- Focusing on the importance of financial and non-financial voluntary disclosure

- Highlighting the concept of stock liquidity in industrial companies.

- Directing beneficiaries to take into account voluntary disclosures in industrial companies.

\subsection{Study Model}

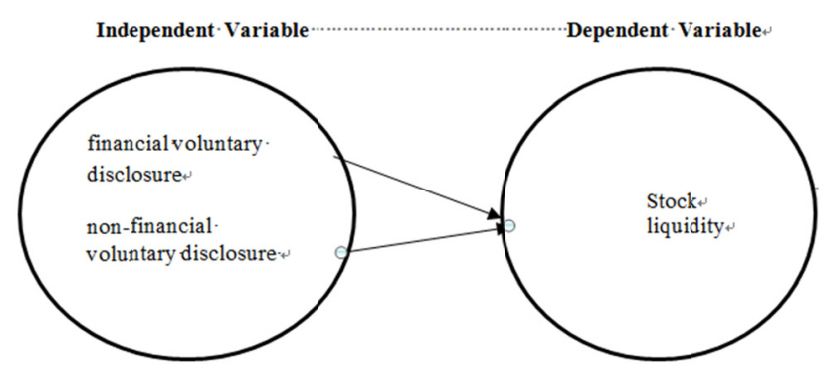

Figure 1. Study model: prepared by the researchers

\section{The Theoretical Framework of the Study}

\subsection{Disclosure}

\subsubsection{Introduction}

Disclosure is still an issue of interest to all parties alike, because disclosure is important in giving a picture of current companies' situation and a glance of its future. Disclosure can be divided in terms of mandatory disclosure and voluntary disclosure as stated in (Dahdouh and Hamada, 2014) as follows: 
Mandatory Disclosure: It is disclosure required by the standards of profession and its legal requirements and according to established regulations in force in a country.

Voluntary Disclosure: It is adding or increasing of information and data by companies to inform decision-makers about financial and non-financial information, which is an addition to voluntary disclosure requirements.

In addition to prior divisions, it is essential to consider what law requires in the articles related to accounting disclosure in Companies Law No. 22 of 1997 and its amendments up to Law No. 57 of 2006, Article 140, Article 141 and Article 142.

\subsubsection{Voluntary Disclosure}

Because of the development of markets, increasing volume of investing in them, increasing number of beneficiaries and their increasing need for data and information concerning companies and the disclosed data by law do not meet beneficiaries' needs, the need was felt for voluntary disclosure.

Given that the study examines the voluntary disclosure issue, the researchers discussed several definitions of voluntary disclosure because it is the subject of research. One of those for example Afifi (2008), which is referred to in Dahdouh and Hamadeh, where voluntary disclosure represents various options for companies to provide accounting information and other information in annual financial reports of companies that appear a appropriate to the decision needs of beneficiaries. The company management decides which information needs to be disclosed and determines the suitability of information for the different parties in decision-making.

Alam (2007) defines voluntary disclosure, as it is a disclosure of the information monopolized by management of the company and there is no obligation to disclose it and here self-motivation is intended to achieve economic benefits.

Mark (2009) stated that voluntary disclosure is providing additional information more than legal requirements.

Unuagbon \& Oziegbe (2016) also explained that voluntary disclosure in accounting is only the disclosure of information that goes beyond the mandatory limits of information in terms of content.

The researchers conclude that voluntary disclosure is only:

- Providing additional information on legal and professional requirements.

- Multiple options by company management, in line with the external parties and external environment.

- Financial and non-financial information regarding decision makers.

\subsubsection{Types of Voluntary Disclosure}

AL-Shatarat et al. (2010) divided voluntary disclosure into 62 items, divided into three groups:

- Financial voluntary disclosure: where financial aspect shows amounts spent by companies and they are not obliged by law to disclose them.

- Non-financial voluntary disclosure: they are procedures or matters within the company that have no financial impact on the company, but it disclosed about it reflecting an indication about the company.

- Strategic voluntary disclosure: shows company objectives and the procedures taken to achieve these objectives as well as maintaining, increasing current and future market position and how to develop it. In addition to providing information on inflation and its effects on the company.

Al-Safadi (2015) and Gray et al. (1995) also emphasized the previous divisions as they also divided voluntary disclosure into financial, non-financial and strategic.

\subsubsection{Importance of Voluntary Disclosure}

Voluntary disclosure is considered one of the signs that show companies' transparency and validity alike. The greater the disclosure, the greater the investors' confidence in companies, as that voluntary disclosure helps to take long-term and short-term decisions. Matar and Al-Sweiti (2012) state that importance of disclosure is obvious in providing appropriate information to the categories that use accounting data for making economic decisions concerning the entity issuing the data. Additionally, providing some financial indicators that enable these categories to predict some of the key changes of the entity, for instance its ability to pay short-term or long-term liabilities.

Al-Sayyed (2003) added that it improves the efficiency of allocating available resources, avoiding or reducing political costs because of actions and methods by States, reducing capital costs and improving the quality of 
decisions taken.

In addition, that mandatory disclosure of information to companies does not meet the investors varied needs of information, so voluntary disclosure is necessary as it has a positive impact on communication between company management and the relevant parties. Voluntary disclosures also mitigate the discrepancy in investors' information.

Voluntary disclosure also improves the quality of disclosed information in terms of the fact that voluntary disclosures can give detail and depth more than mandatory disclosures improve information credibility, its completeness and expansion and enhance the protection of investor interests.

Soliman (2013) states that voluntary disclosure is important and required for capital market efficiency. The more information the company discloses, the more the information becomes transparent to investors. Less voluntary disclosure means less inconsistency in information, more disclosed information means more voluntary disclosure. When voluntary disclosure increases, validity increases.

Zarb (2015) also indicates that accounting voluntary disclosure of information increases transparency and increases investor confidence.

The researchers conclude that voluntary disclosure is considered complementary to mandatory disclosure, so that it clarifies and expands information that must be added by the company, which helps investors and internal, external parties to make their decisions.

\subsubsection{Voluntary Disclosure (FASB)}

Al-Shalahi (2012) referred to the recommendations of Financial Accounting Standards Board (FASB) in 2001 regarding voluntary disclosure as follows:

1- Voluntary disclosure of business data, particularly important operational information and disclosure of performance measures adopted by companies.

2- Management perform analysis work data, i.e. disclosure of management analysis for reasons of change in operational data and data related to performance measures, as well as disclosure of change positively or negatively.

3- Disclosure of future information, i.e., disclosure of expectations or future predictions about opportunities and risks arising from positive or negative trends of performance indicators, companies and enterprises plans connected to organization success and comparison of current performance indicators with previous performance indicators.

4- Disclosure of information about managers and management, their financial allocations, major shareholders and relationships with external parties.

5- Disclosure of objectives and general strategies of companies, in addition to impact of companies within the same sector on the company.

6- Voluntary disclosure of information concerning intangible assets that is not disclosed in the financial statements.

\subsubsection{Factors Affecting Voluntary Disclosure}

In view of importance of voluntary disclosure, Abed Al-Jalil and Abu Nassar (2014) divided the factors affecting voluntary disclosure into four factors, under which there several items:

- Internal parties

Members of the board of directors, chairman of the board of directors, general director, deputies of general manager, financial manager, head of accounts department, company's auditors, internal auditor and external auditor.

- External parties

Jordanian companies law, income tax law, sales tax law, Jordan Securities Commission instructions, industry procedures (companies operating in the same sector), international accounting standards, shareholder proposals, shareholders, lenders.

- $\quad$ Satisfying the needs of information users

Current investors, prospective investors, creditors from financial institutions, commercial creditors, financial analysts, scholars and researchers, government agencies, and company employees. 


\section{- $\quad$ Expected benefits}

Increase in the market value of company's stock, stability in company's stock prices, assisting the company to borrow, reducing interest rates, improving the company's image to stakeholders, reducing the board's responsibility towards shareholders, helping shareholders to familiarize themselves with company's profitability and its financial position and reducing the risk of rumors on the company.

\subsection{Stocks Liquidity}

\subsubsection{Definition of Stocks Liquidity}

There are numerous definitions of stock liquidity that the researchers summarize as follows:

Hanan's definition (Hanan, 2013, p. 107): It expresses the amount of time that is expected to pass before an asset becomes cash or before paying a certain obligation.

It is also known the ability to buy or sell stocks quickly and in large quantities without any significant impact on other prices in the market and without incurring high selling costs. As reported in Arar referred to in (Ma et al, 2015).

(Indian and others, 2006) define it as the ease of marketing i.e., the possibility of buying or selling a banknote at a very close price to the price at which the last transaction was made on that paper, on the assumption that there is no new information for the market.

From these definitions, we can conclude that the stocks liquidity depends on two important factors:

* Speed: It is possible to sell stock quickly because there are prospective buyers due to the company's performance.

* Price: It is probable to sell the stock without significantly affecting its price.

\subsubsection{Importance of Stock Liquidity}

Stock liquidity has a great significance to investors in the market as investors accept trading stocks with high liquidity as they achieve their objectives without exposing themselves to various risks regarding stocks that are represented in decreasing its value, incurred high costs of disposal or loss of alternative investment opportunities.

Traders are expected to buy stocks at a high price provided they have high liquidity and vice versa. Traders will not buy securities with low liquidity unless they have low price to the point of compensating the losses they have while trying to sell them at the time they want. Furthermore, the concept of stock liquidity has great importance for companies issuing those stocks, the stocks they issue and sold at a high price because of their liquidity have a direct impact represented by high market value of the stocks issued by these companies that have high liquidity. In addition to indirect impact represented by increasing the amount of issuance because of selling the stocks with a high price since its high liquidity, which leads to a decrease in money costs and an increase in the market value as well (Kfouri,2013).

Investors afraid that their savings will remain in the markets for long periods, but high-liquidity capital markets and companies in these markets enjoy fast access to capital through issuing stocks and this reduces investor risk and increases his desire to invest in these markets that have liquidity as well as they facilitate long-term investments (Lambert, 2007).

Researchers consider from foregoing that stocks liquidity are among important factors for companies that they must maintain a certain or minimum amount of liquidity because of its positive effects on stocks.

\subsubsection{Factors Affecting Stocks Liquidity}

- Proportion of stocks owned by strategic shareholders and long-term investors affects on the proportion of free stocks. Free stocks are defined as the company's stocks that are available for daily trading in the market and they do not include stocks owned by board of directors of the company and their relatives and stocks owned by parent companies affiliate, subsidiaries stocks owned by shareholders own $5 \%$ or more of the company's capital (treasury stocks) and thus affect the liquidity of traded stocks.

- Market value of the stock: It affects stocks liquidity, whereas stocks with a large value have less liquidity than stocks with low market value, therefore some companies split their stocks to enhance its stocks liquidity.

- Company's reputation, its financial performance and ability to achieve profits and distribute them.

- Company's capital: The company's capital interferes in determining turnover rate of the stock and thus affects its liquidity (Kfouri, 2013). 
Kfouri affirms referred to in (Hindi et al., 2006) that if the security's market has depth, breadth and flexibility, this will bring for it a high degree of liquidity.

\subsubsection{Measuring Stock Liquidity}

Stock liquidity can be measured by stock turnover, which results from dividing number of stocks sold and purchased during the year by number of stocks subscribed during the same year, which is published in Jordanian public joint stock companies manual (Amman Stock Exchange, 2018).

Share turnover $=$ (number of shares traded during the period $/$ number of shares written at the end of the period) (ASE, 2018).

\section{Literature Review}

Aldarahli's Study (2017) Impact of financial factors of companies on stocks liquidity.

This study aimed to explain the impact of financial factors of Jordanian industrial shareholding companies listed on Amman Stock Exchange that include assets liquidity, debt rate, profitability and degree of financial leverage as independent variables, to study their impact on the stocks liquidity, which represents the dependent variable.

The study concluded that stocks liquidity is affected positively at a significant level of $1 \%$ in assets liquidity, debt rate, profitability, and degree of financial leverage, although this impact varies from one variable to another. The most important recommendations of this study are to guide further studies and future research to issues regarding subject of the study. This subject is considered multi-pronged, which is difficult to cover it in one study and apply it on service and financial sectors.

Al-Qahtani's Study (2015): Impact of corporate governance mechanisms on stock market liquidity: An applied study on public shareholding financial companies.

This study aimed to examine the impact of governing mechanisms on of stock market liquidity in Jordanian financial shareholding companies listed on Amman Stock Exchange, the researcher emphasizes on corporate governance in terms of the need to separate the board of directors and major shareholders.

Based on these study findings, the researcher proposed several recommendations, most important, studying determining the optimum number of board of directors to be in line with the company's practices and strategies concerning liquidity component. Furthermore, studying the percentage of ownership of major owners and their impact on liquidity.

Albitar's Study (Albitar, 2015) entitled "Corporate characteristics and governance characteristics and their relationship to voluntary disclosure: A Study of Jordanian companies listed on Amman Stock Exchange"

The objective of this study was to measure the level of voluntary disclosure in the annual reports of Jordanian companies listed on Amman Stock Exchange and it examined the relationship among a number of explanatory variables and voluntary disclosure level.

The study found that the level of voluntary disclosure in annual reports of Jordanian companies is low. One-way analysis of variance (ANOVA) revealed that there is a statistically significant positive effect of ( the size of company, degree of financial leverage, company age, profitability, liquidity, size of board of directors and size of audit committee) on the level of voluntary disclosure. Whereas there is a statistically significant negative impact of non-executive managers and possession structure on the level of voluntary disclosure.

The study recommended researchers that they should take into account the use of information available on the Internet as a recent advance in technology and communication that helps researchers, in addition to researchers recommend that the study should include countries of the Middle East and Jordan to compare Jordan with other developed countries in the Middle East, particularly those countries are governed by different disclosure laws.

Kasim's Study (Kasim, 2015) entitled Effect of voluntary disclosure and share liquidity of the capital market in Indonesian Stock Exchange

This study discussed disclosure regarding information resulting from accounting processes, where investors make their decisions and the researchers used this information to study the extent of investors' assessment of information disclosed by the company.

In addition, the study examined the relationship between disclosure and liquidity in the market, which can be seen in difference in price between supply and demand, i.e., the difference between the highest price a trader or investor can buy and the lowest price a trader or investor can sell. To see the effect of disclosure on liquidity, the results showed that the relation between disclosure and liquidity Stocks was not significant and this indicates that investors are not responding very much to the information disclosed and is due to that the capital market in 
Indonesia is still emerging.

Kfouri's Study (2013): Factors affecting the stocks liquidity in Amman Stock Exchange

The main objective of this study was to reveal some of the factors affecting stocks liquidity traded in Amman Stock Exchange by examining the relationship between ordinary stock liquidity measured by the turnover rate and some commonly used accounting variables that investors usually depend on when making their deep stock investment decisions regarding stock trading like: market value of ordinary stock, ordinary stock profitability, ordinary stock cash dividends, rate of return on assets, rate of return on equity.

The study concluded that there is a statistically significant relationship among ordinary stock liquidity measured by turnover rate and the market value of ordinary stock, ordinary stock earnings and ordinary stock cash dividends, while there is no significant statistically relationship between ordinary stock liquidity measured by its turnover and the rate of return on assets and rate of return on equity.

The study recommended that the shareholding companies that their stocks are traded on Amman Stock Exchange should pay attention to those variables that have a moral effect on ordinary stock liquidity in order to increase their stocks liquidity.

\section{Method and Procedures}

\subsection{Introduction}

This chapter addresses the procedures and methods adopted by the researchers to achieve objectives of this study, which included methodology applied in the study, population and sample, as well as the most important statistical methods used in processing the data collected.

\subsection{Study Methodology}

The researchers used the descriptive analytical method through the following steps:

1- Identifying the problem by reviewing the previous studies, laws and regulations governing the work of industrial shareholding companies listed on Amman Stock Exchange and related standards.

2- Identifying study hypotheses, which represent proposed solutions to the elements of study problem.

3- Collecting the required data with the aim of developing a theoretical framework to identify the concepts contained in the hypotheses.

4- Collecting the required data to test hypotheses through annual reports issued by industrial shareholding companies listed on Amman Stock Exchange in 2016.

5- Analyzing data.

6- Testing hypotheses and reaching to conclusions and recommendations.

\subsection{Sources of Information Collection}

Because of the importance of the topics listed this study, the researchers followed the analytical descriptive approach, and relied on accessing data and information from two sources of data collection, namely:

- Initial sources: Annual reports issued by annual reports issued by industrial shareholding companies listed on Amman Stock Exchange in 2016 to obtain the required data to achieve the study objective.

- Secondary sources: It is data obtained from researches, books, periodicals, journals, literature review, websites, specia4l publications or subject matter under study.

\subsection{Population and Sample}

Study population consisted of 60 Jordanian industrial shareholding companies listed on Amman Stock Exchange, based on (Amman Stock Exchange) dated 4/3/2018, the industrial sector was chosen due to it is a large sector.

The randomized multi-sector sample was used to include all industrial sectors listed on Amman Stock Exchange.

Whereas study sample consisted of 30 companies, where the necessary data was extracted from financial reports of industrial companies.

\subsection{Measurement of Study Instrument}

\section{- Independent variable (voluntary disclosure)}

The researchers used the unbalanced method to determine the extent to which industrial shareholding companies listed on Amman Stock Exchange abide by disclosure requirements. The researchers used double scale for the items (1) disclosed items and (0) for not disclosed ones, and then the voluntary disclosure average for each 
company was calculated by the following equation:

Voluntary disclosure average $=($ Number of items disclosed by the company / total items applicable to that company) * 100 .

So that the smallest disclosure correlation is zero, if the company does not disclose the items applicable to it. The maximum margin is $100 \%$ if the company has disclosed all the items that applicable to it.

The researchers also used a three-point scale to measure the degree of assessment of disclosure average of each company, divided into three levels. The cut-off score was calculated by dividing the difference between the highest value of voluntary disclosure average of each company and the lowest value of voluntary disclosure average of each company. This means that the cut-off score as follows: (highest value of voluntary disclosure average - lowest value of voluntary disclosure average / 3). Thus, the three levels are as follows:

Table 1. Scale of degree of importance (Voluntary Disclosure)

\begin{tabular}{|c|c|c|c|c|}
\hline Importance & & High & Medium & Low \\
\hline $\begin{array}{l}\text { Voluntary } \\
\text { Average }\end{array}$ & Disclosure & less than $33 \%$ & from 33 to $67 \%$ & more than $67 \%$ \\
\hline
\end{tabular}

- Dependent variable (Stocks liquidity of Jordanian industrial companies)

Stocks liquidity of Jordanian industrial companies was calculated by calculating the stocks turnover average for these companies according to the following equation:

Stocks turnover average $=($ Number of stocks traded during the period $/$ number of stocks subscribed at the end of the period)

\section{Study Limitations}

A- Spatial limits: This study was conducted on industrial shareholding companies listed on Amman Stock Exchange $\mathrm{t}$.

B- Time Limits: This study was conducted on financial reports of industrial shareholding companies listed on Amman Stock Exchange in 2016.

\section{Statistical methods used in this study}

The appropriate statistical methods were used in statistical analysis program SPSS in order to process the data obtained through field study. Specifically, the researchers used the following statistical methods:

1- Arithmetic Mean: To find out the extent of high or low voluntary disclosure is, for the study sample of industrial shareholding companies listed on Amman Stock Exchange in 2016.

2- Standard Deviation: It was used to determine the dispersion of voluntary disclosure of the study sample from arithmetic mean values.

3- Multiple Regression: It was used to measure the impact of voluntary disclosure on stock liquidity for Jordanian industrial shareholding companies listed on Amman Stock Exchange.

4- Simple Regression: It was used to determine impact of financial and non-financial voluntary disclosure on stock liquidity for Jordanian industrial shareholding companies listed on Amman Stock Exchange.

\subsection{Analysis of Results and Hypothesis Testing}

In this chapter, the researchers analyze the data and test study hypotheses through answering the study items and reviewing the most important results obtained through analyzing data. Statistical processing of collected data was done. The researchers used statistical program SPSS. Several statistical methods were used to analyze the collected data in a way that would achieve the study objectives, which will be presented and analyzed in this chapter.

\section{Results of Descriptive Statistics of Study Data}

To reach to study objectives, the researchers examined and analyzed financial reports of (30) Jordanian industrial shareholding companies as a random sample of the total number of the companies (60 companies), which their stocks are traded on Amman Stock Exchange.

The researchers prepared a voluntary disclosure indicator consists of (28) items to measure voluntary disclosure 
in the study sample: Jordanian industrial shareholding companies listed on Amman Stock Exchange. Those were deduced from disclosure requirements in Jordanian laws and regulations. With the purpose of calculating voluntary disclosure average for these companies, the financial reports of the study sample of 2016 were examined as the most recent issued by them until this date. These reports were studied to investigate the extent to which each of these companies have done their voluntary disclosure using (28) items mentioned in Table (2).

Table 2. Voluntary Disclosure Items for Jordanian Industrial Companies

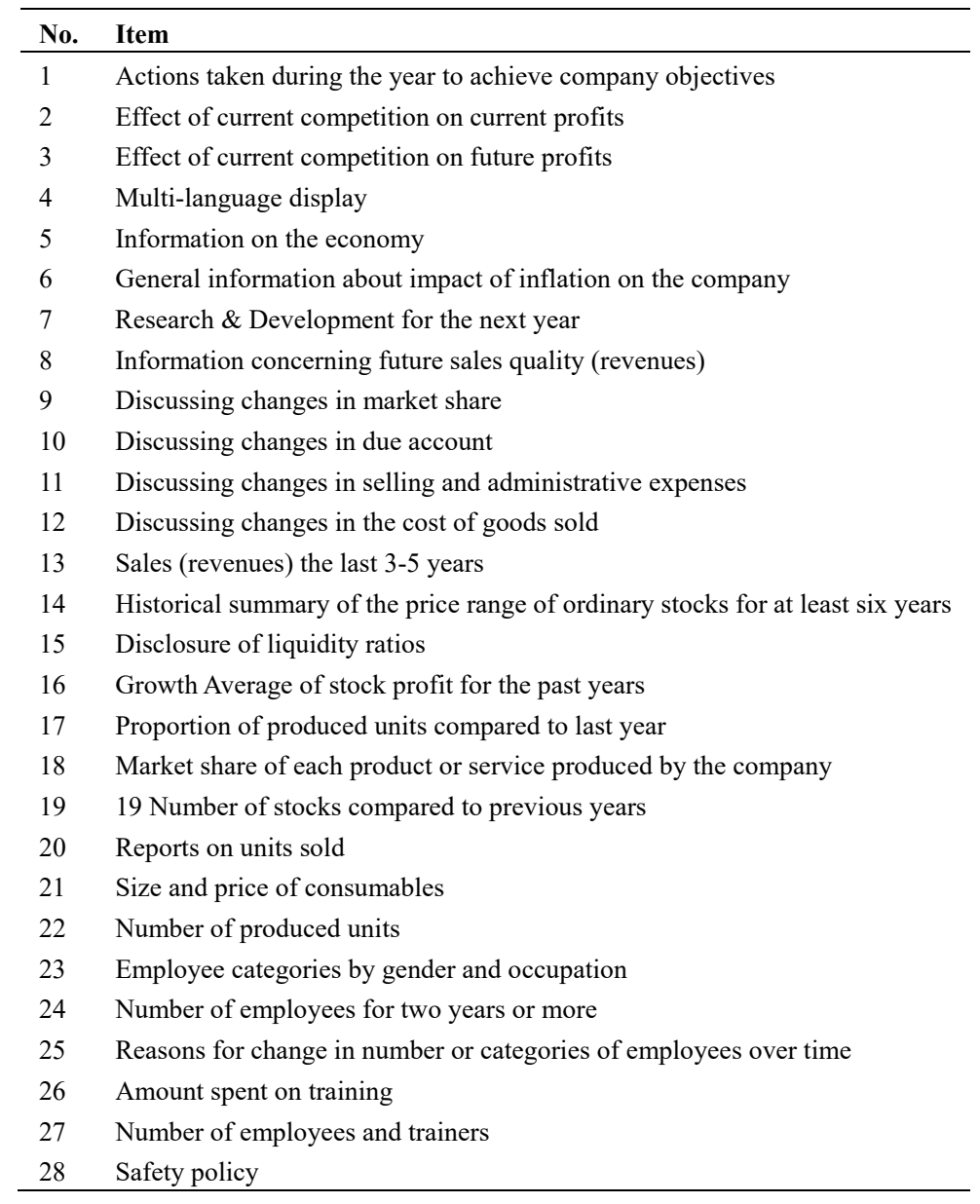

\subsection{Analysis of Study Data}

Study items were analyzed and discussed in light of the questions and hypotheses identified by the researchers through using both arithmetical averages and standard deviations.

\section{Results Regarding Answering the Study Question}

Is there an impact of voluntary accounting disclosure on stock liquidity for Jordanian industrial shareholding companies listed on Amman Stock Exchange?

With the intention of answering the study question, the researchers calculated arithmetical averages and standard deviations of voluntary accounting disclosure on stock liquidity for Jordanian industrial shareholding companies listed on Amman Stock Exchange with the aim of determining the degree of interest in each of the items mentioned above and diagnosing their dispersion from their arithmetical averages as follows:

A- Is there an impact of financial voluntary disclosure on stock liquidity for Jordanian industrial shareholding companies listed on Amman Stock Exchange?

The results presented in Table (3) indicate that the general arithmetic average of the financial voluntary disclosure degree on stock liquidity for Jordanian industrial shareholding companies listed on Amman Stock Exchange was (0.69) with a standard deviation of (0.18). 
Table 3. Arithmetic averages and standard deviations of financial voluntary disclosure on stock liquidity for jordanian industrial shareholding companies listed on Amman stock exchange

\begin{tabular}{lllll}
\hline No. & Item & $\begin{array}{l}\text { Arithmetic } \\
\text { Average }\end{array}$ & $\begin{array}{l}\text { Standard } \\
\text { Deviation }\end{array}$ & $\begin{array}{l}\text { Disclosure } \\
\text { Degree }\end{array}$ \\
\hline 1 & Actions taken during the year to achieve company objectives & 1.00 & 0.00 & High \\
2 & Effect of current competition on current profits & 1.00 & 0.00 & High \\
3 & Effect of current competition on future profits & 0.80 & 0.41 & High \\
4 & Research \& Development for the next year & 0.57 & 0.50 & Medium \\
5 & Information concerning future sales quality (revenues) & 0.40 & 0.50 & Medium \\
6 & Discussing changes in market share & 0.67 & 0.48 & High \\
7 & Discussing changes in due account & 0.43 & 0.50 & Medium \\
8 & Discussing changes in selling and administrative expenses & 0.34 & 0.48 & Medium \\
9 & Discussing changes in the cost of goods sold & 0.60 & 0.50 & Medium \\
10 & Sales (revenues) the last 3-5 years & 0.80 & 0.41 & High \\
11 & Disclosure of liquidity ratios & 0.87 & 0.35 & High \\
12 & Growth Average of stock profit for the past years & 0.83 & 0.38 & High \\
13 & Reports on units sold & 0.50 & 0.51 & Medium \\
14 & Size and price of consumables & 0.87 & 0.35 & High \\
All Item & & 0.69 & 0.18 & High \\
\hline
\end{tabular}

The results presented in Table 3 indicate that the financial voluntary disclosure degree on stock liquidity for Jordanian industrial shareholding companies listed on Amman Stock Exchange was high, whereas its arithmetic averages was (1.00-0.34) compared with the general arithmetic average of financial voluntary disclosure degree on stock liquidity for Jordanian industrial shareholding companies listed on Amman Stock Exchange a standard that was $(0.69)$.The disclosure, which states: "Actions taken during the year to achieve company objectives" and disclosure "Effect of current competition on current profits" ranked first with an average (1) and a standard deviation (0.0). while the disclosure " Discussing changes in selling and administrative expenses " was ranked last with an average of (0.34).

Table 4. Arithmetic averages and standard deviations of non-financial voluntary disclosure on stock liquidity for Jordanian industrial shareholding companies listed on Amman Stock Exchange

\begin{tabular}{|c|c|c|c|c|}
\hline No. & Item & $\begin{array}{l}\text { Arithmetic } \\
\text { Average }\end{array}$ & $\begin{array}{l}\text { Standard } \\
\text { Deviation }\end{array}$ & $\begin{array}{l}\text { Disclosure } \\
\text { Degree }\end{array}$ \\
\hline 1 & Multi-language display & 1.00 & 0.00 & High \\
\hline 2 & Information on the economy & 0.90 & 0.30 & High \\
\hline 3 & General information about impact of inflation on the company & 0.34 & 0.48 & High \\
\hline 4 & $\begin{array}{l}\text { Historical summary of the price range of ordinary stocks for at } \\
\text { least six years }\end{array}$ & 0.93 & 0.25 & High \\
\hline 5 & Proportion of produced units compared to last year & 0.90 & 0.31 & High \\
\hline 6 & Market share of each product or service produced by the company & 0.20 & 0.41 & Low \\
\hline 7 & Number of stocks compared to previous years & 0.97 & 0.18 & High \\
\hline 8 & Number of produced units & 0.47 & 0.51 & Medium \\
\hline 9 & Employee categories by gender and occupation & 0.70 & 0.47 & High \\
\hline 10 & Number of employees for two years or more & 0.50 & 0.51 & Medium \\
\hline 11 & $\begin{array}{l}\text { Reasons for change in number or categories of employees over } \\
\text { time }\end{array}$ & 0.23 & 0.43 & Low \\
\hline 12 & Amount spent on training & 0.30 & 0.47 & Low \\
\hline 13 & Number of employees and trainers & 0.53 & 0.51 & Medium \\
\hline 14 & Safety Policy & 0.60 & 0.49 & Medium \\
\hline \multicolumn{2}{|c|}{ All Items } & 0.61 & 0.13 & Medium \\
\hline
\end{tabular}


It is clear from the results shown in Table(4) that the financial voluntary disclosure degree on stock liquidity for Jordanian industrial shareholding companies listed on Amman Stock Exchange was medium, whereas its arithmetic averages was (1.00-0.20) compared with the general arithmetic average of non-financial voluntary disclosure degree on stock liquidity for Jordanian industrial shareholding companies listed on Amman Stock Exchange a standard that was (0.61).The disclosure, which states: "Multi-language display" ranked first with an average (1) and a standard deviation (0.0). while the disclosure "Market share of each product or service produced by the company" was ranked last with an average of $(0.20)$.

The researchers depended on the study of (AL-Shatarat et al., 2010) in dividing items into financial and non-financial.

\subsection{Results of Testing Study Hypotheses}

\subsubsection{Testing Major Hypothesis}

There is no impact of voluntary disclosure on stock liquidity for Jordanian industrial shareholding companies listed on Amman Stock Exchange at significance level $(\alpha . \leq 0.05)$.

To test this hypothesis, the researchers used multiple regression analysis to measure the impact of voluntary disclosure on stock liquidity for Jordanian industrial shareholding companies listed on Amman Stock Exchange at significance level $(\alpha . \leq 0.05)$. Results that is presented in table (5) show the following:

Table 5. Test results of multiple regression analysis to measure impact of voluntary disclosure on stock liquidity for Jordanian industrial companies

\begin{tabular}{|c|c|c|c|c|c|c|}
\hline $\begin{array}{l}\text { Independent } \\
\text { Variable }\end{array}$ & $\begin{array}{l}\text { Source of } \\
\text { Variance }\end{array}$ & Sum of Squares & $\begin{array}{l}\text { Degrees of } \\
\text { Freedom }\end{array}$ & f-Value & $\begin{array}{l}\text { Significance } \\
\text { Level }\end{array}$ & $\begin{array}{l}\text { Statistical } \\
\text { Decision }\end{array}$ \\
\hline Voluntary & Regression & 3223.704 & 2 & & & Accepting \\
\hline \multirow[t]{2}{*}{ Financial } & Error & 535219.514 & 27 & & & null \\
\hline & Total & 538443.218 & 29 & 0.081 & 0.922 & hypothesis \\
\hline$R^{2}$ value & 0.006 & & & & & \\
\hline$\beta$ value & $\mathbf{0 . 0 7 7}$ & & & & & \\
\hline
\end{tabular}

f- tabulated value at significance level $(\alpha \leq 0.05)$ and degree of freedom $(27-2)=3.35$.

It is clear from the data in previous table that calculated F- value is 0.081 , where its tabulated value is 3.35 . By comparing the values obtained in from testing this hypothesis, it is found that the calculated value is less than the tabulated value. Thus, the null hypothesis is accepted and the alternative hypothesis is accepted that indicates there is a statistically significant impact of voluntary disclosure on stock liquidity for Jordanian industrial shareholding companies listed on Amman Stock Exchange at significance level $(\alpha \leq 0.05)$. This is confirmed by the value of significance level $(\alpha=0.922)$ which is greater than significance level $(\alpha \leq 0.05)$.

The explanation of that there is no impact of voluntary disclosure on stock liquidity by the researchers' view, that the investors concentrate on mandatory disclosures under laws and standards rather than voluntary disclosures. As far as the researchers know, there are no studies their results are in agreement with the results of this aspect of this study, that there is a difference with the study results (Al-Sha'ar et al., 2015)

With respect to testing the sub-hypotheses arising from this hypothesis, the following tables show the results that were obtained:

\subsubsection{Testing the First Sub-Hypothesis}

There is no impact of financial voluntary disclosure on stock liquidity for Jordanian industrial shareholding companies listed on Amman Stock Exchange at significance level ( $\alpha . \leq 0.05)$.

To test this hypothesis, the researchers used simple regression analysis to measure the impact of financial voluntary disclosure on stock liquidity for Jordanian industrial shareholding companies listed on Amman Stock Exchange at significance level $(\alpha . \leq 0.05)$. The results in Table (6) The following: 
Table 6. Test results of simple regression analysis to measure impact of financial voluntary disclosure on stock liquidity for Jordanian industrial companies

\begin{tabular}{|c|c|c|c|c|c|c|c|}
\hline $\begin{array}{l}\text { Independent } \\
\text { Variable } \\
\end{array}$ & $\begin{array}{l}\text { Source of } \\
\text { Variance }\end{array}$ & Sum of Squares & $\begin{array}{l}\text { Degrees of } \\
\text { Freedom }\end{array}$ & F-value & t-value & $\begin{array}{l}\text { Significanc } \\
\text { e Level }\end{array}$ & $\begin{array}{l}\text { Statistical } \\
\text { Decision }\end{array}$ \\
\hline Voluntary & Regression & 2414.653 & 1 & & & & \\
\hline Financial & Error & 536028.564 & 28 & & & & Rejecting null \\
\hline Disclosure & Total & 538443.218 & 29 & 0.126 & 0.355 & 0.725 & hypothesis \\
\hline $\mathbf{R}^{2}$ value & 0.004 & & & & & & \\
\hline$\beta$ value & 0.067 & & & & & & \\
\hline
\end{tabular}

t- tabulated value at significance level $(\alpha \leq 0.05)$ and degree of freedom of $29=2.05$.

It is clear from the data in previous table that t-calculated value is 0.355 , whereas its tabulated value is 2.05 . By comparing the values obtained in from testing this hypothesis, it is found that the calculated value is less than the tabulated value. Thus, the null hypothesis is accepted and the alternative hypothesis is rejected that indicates there is a statistically significant impact of financial voluntary disclosure on stock liquidity for Jordanian industrial shareholding companies listed on Amman Stock Exchange at significance level $(\alpha \leq 0.05)$. This is confirmed by the value of significance level $(\alpha=0.725)$ which is greater than significance level $(\alpha \leq 0.05)$.

\subsubsection{Testing the Second Sub-Hypothesis}

There is no impact of non-financial voluntary disclosure on stock liquidity for Jordanian industrial shareholding companies listed on Amman Stock Exchange at significance level $(\alpha . \leq 0.05)$.

To test this hypothesis, the researchers used simple regression analysis to measure the impact of non-financial voluntary disclosure on stock liquidity for Jordanian industrial shareholding companies listed on Amman Stock Exchange at significance level $(\alpha . \leq 0.05)$.The results in Table (7) show the following:

Table 7. Test results of simple regression analysis to measure impact of financial voluntary disclosure on stock liquidity for Jordanian industrial companies

\begin{tabular}{lllllll}
\hline $\begin{array}{l}\text { Independent } \\
\text { Variable }\end{array}$ & $\begin{array}{l}\text { Source } \\
\text { Variance }\end{array}$ & of & Sum of Squares & $\begin{array}{l}\text { Degrees of } \\
\text { Freedom }\end{array}$ & F-value & $\begin{array}{l}\text { Significance } \\
\text { Level }\end{array}$ \\
\hline Voluntary & Regression & $\mathbf{1 5 2 7 . 4 5 6}$ & $\mathbf{1}$ & $\begin{array}{l}\text { Statistical } \\
\text { Decision }\end{array}$ \\
Non-Financial & Error & $\mathbf{5 3 6 9 1 5 . 7 6 2}$ & $\mathbf{2 8}$ & & Rejecting null \\
Disclosure & Total & $\mathbf{5 3 8 4 4 3 . 2 1 8}$ & $\mathbf{2 9}$ & $\mathbf{0 . 0 8 0}$ & $\mathbf{0 . 2 8 2}$ & $\mathbf{0 . 7 8 0}$ \\
$\mathbf{R}^{2}$ value & $\mathbf{0 . 0 0 3}$ & & & & & hypothesis \\
$\boldsymbol{\beta}$ value & $\mathbf{0 . 0 5 3}$ & & & & \\
\hline
\end{tabular}

$\mathrm{t}$ - tabulated value at significance level $(\alpha \leq 0.05)$ and degree of freedom of $29=2.05$.

It is obvious from the data in preceding table that $\mathrm{t}$-calculated value is 0.282 , whereas its tabulated value is 2.05 . By comparing the values obtained in from testing this hypothesis, it is found that the calculated value is less than the tabulated value. Thus, the null hypothesis is accepted and the alternative hypothesis is rejected that indicates there is a statistically significant impact of non-financial voluntary disclosure on stock liquidity for Jordanian industrial shareholding companies listed on Amman Stock Exchange at significance level $(\alpha \leq 0.05)$. This is confirmed by the value of significance level $(\alpha=0.780)$ which is greater than significance level $(\alpha \leq 0.05)$.

Finally, the researchers summarized the results of testing study hypotheses and table (8) shows a summary of results of testing study hypotheses as follows:

\section{Hypothesis}

Major Hypothesis

First

\section{Decision}

There is no impact of voluntary disclosure on stock liquidity for Jordanian industrial shareholding companies listed on Amman Stock Exchange

There is no impact of financial voluntary disclosure on stock liquidity for Jordanian 
Sub-Hypothesis industrial shareholding companies listed on Amman Stock Exchange

Second

Sub-Hypothesis

There is no impact of non-financial voluntary disclosure on stock liquidity for Jordanian industrial shareholding companies listed on Amman Stock Exchange

\section{Results and Recommendations}

In consideration of study data analysis in Chapter 4, this chapter includes an overview of discussing the study results. Such as, answering the questions rose in the first chapter of this study, which represented its problem and the hypotheses that were based on it. This chapter also contains the most significant recommendations that reached by this study in view of the results.

\subsection{Results}

Based on data statistical analysis that were collected to achieve study objectives and its problem, and depending on testing study hypotheses, it is clear that the study results are summarized in the following points:

1- Study results showed that the level of financial voluntary disclosure for Jordanian industrial shareholding companies listed on Amman Stock Exchange was high, where disclosure average for companies in 2016 was $69 \%$.

2- Study results showed that the level of non-financial voluntary disclosure for Jordanian industrial shareholding companies listed on Amman Stock Exchange was medium. Whereas, disclosure average for companies in 2016 was $61 \%$.

3- Study results showed that financial voluntary disclosure has no impact on stock liquidity for Jordanian industrial shareholding companies listed on Amman Stock Exchange. This indicates that the investor does not pay much attention to financial disclosure of the company when making the decision to trade in the stock. Possibly the price limits imposed by the market management reduce risk that the investor may bear. Consequently, these risks will not be affected by any of the studied variables. Therefore, there is no impact of company's disclosure level on the market return of its stocks due to there is no relationship between the level of non-financial disclosure and price risk borne by the investor.

4- Study results showed that non-financial disclosure has no impact on stock liquidity for Jordanian industrial shareholding companies listed on Amman Stock Exchange. This indicates that the investor does not pay much attention to non-financial disclosure of the company when making the decision to trade in the stock. As a result, these risks will not be affected by any of the studied variables. Accordingly, there is no impact of company's disclosure level on the market return of its stocks due to there is no relationship between the level of disclosure and price risk borne by the investor.

The researchers report that the absence of that there is no statistically significant impact of voluntary disclosure on stock liquidity is due to weakness in financial market which is reflected by financial statements of the companies.

\subsection{Recommendations}

According to the findings of the study theoretical framework, as well as from data statistical analysis of the, a number of recommendations can be suggested as follows:

1- Directing investors to the information contained in financial reports to help them make suitable and rational investment decisions by drawing their attention to all items in the financial reports and not focusing on specific indicators, since the information contained in financial reports will reflect a clear picture of the entity's status.

2- Organizers of the work of shareholding companies must oblige these companies to provide information that is more useful to the shareholders to aid them in making investment decisions by transferring disclosure items that concern investors from voluntary to mandatory, as this is important in increasing investors' confidence and assurance.

3- Working to raise and improve information disclosure level contained in financial reports through the joint efforts of shareholding companies, auditors and securities commissions. In addition to developing legislations to keep pace with the developments and enhance the process of information disclosure to meet the needs of investors, rationalize their decisions and increase confidence in financial reports.

4- Broadening the role of supervisory bodies to which the shareholding companies are governed by, so that their role is not limited to monitoring submission disclosures by shareholding companies, but to providing such disclosures in a timely manner and the need to take action that will oblige companies not to delay issuing financial statements and annual reports whereas, providing information late loses value of this information and 
its effectiveness for the beneficiaries

\section{References}

Abed Al-Jalil, T. H., \& Abu Nassar, M. (2014). Factors affecting the level of voluntary disclosure in annual financial reports of Jordanian shareholding companies. Administrative Sciences, 161(1524), 1-40.

Afifi, H. A. F. (2008). Relationship between the application of corporate governance and level of voluntary disclosure in the annual reports: A test study in Egyptian environment. Journal of commercial research, 30(1), 429-498.

Al Shattarat, W., Haddad, A., \& Al-Hares, O. (2010). The extent of voluntary disclosure in an emerging capital market: The case of Jordan. Journal of Modern Accounting and Auditing, 6(10), 39-51.

Alam, J. (2007). Financial Disclosure in Developing Countrieswith Special Reference to Bangladesh. Unpublished Dissertation, PhDin accounting, Ghent University, Belgium.

Albitar, K. (2015). Firm characteristics, governance attributes and corporate voluntary disclosure: A study of Jordanian listed companies. International business research, 8(3), 1. https://doi.org/10.5539/ibr.v8n3p1

Al-Qahtani, S. (2015). Effect of Corporate Governance on Stock Market Liquidity: An empirical study on Jordanian financial public shareholding companies. Unpublished master thesis. University of Jordan, Amman, Jordan.

Al-Safadi, H. (2015). Inpact of voluntary accounting disclosure in financial reports on rationalizing investors' decisions of industrial companies listed on Amman Stock Exchange. Unpublished master thesis, Zarqa University. Amman, Jordan.

Al-Sayed, S. M. (2003). Economic effects of Egyptian accounting standards - From a market research perspective. Journal of contemporary business research, 17(1), 163-211.

Al-Shalahi, B. (2012). Determining the nature of the voluntary disclosure of human resources in financial reports issued by the industrial shareholding companies in Kuwait. Unpublished master thesis. Middle East University, Amman, Jordan.

Dahdouh, H., \& Hamadeh R. (2014). Role of voluntary disclosure in enhancing confidence in financial reports of companies listed on Damascus Security Exchange: Damascus University. Journal of Economic and Legal Sciences, 30(2), pp.187-197.

Darhili, M. (2017). Impact of financial factors on stock liquidity: A field study on Jordanian industrial shareholding companies. Unpublished master thesis. Zarqa University, Amman, Jordan.

Hanan, R. (2013). Introduction to accounting theory: Intellectual framework and practical applications (3rd ed.). Amman: Dar Wael for Publishing.

Hindi, M. I. (2006). Securities and capital markets. Alexandria, Egypt: Knowledge Establishment.

Kasim, E. Y. (2015). Effect Of Voluntary Disclosure And Share Liouidty Of The Capital Market In Indonesian Stock Exchange. International Journal of Business, Economics and Law, 7(2),13-22.

Kfouri, S. (2013). Factors affecting stocks liquidity in Amman Stock Exchange. Unpublished master thesis. University of Damascus. Damascus, Syria.

Lambert, R., Leuz, C., \& Verrecchia, R. (2007). Accounting information, disclosure, and the cost of capital. Journal of Accounting Research, 45(2), 385-420. https://doi.org/10.1111/j.1475-679X.2007.00238.x

Ma, R., Anderson, H. D., \& Marshall, B. R. (2015). International stock market liquidity: A review. Managerial Finance, 42(2), 118-135. https://doi.org/10.1108/MF-04-2015-0096

Marek, S. M. (2009). Measuring voluntary disclosure level in published financial reports of Saudi shareholding companies. King Abdulaziz University Journal: Economics and Management, 23(1), 131-174.

Matar, M. \& Al-Sayoti, M. (2012). Theoretical foundation of accounting professional practices in the fields of: Measurement, presentation and disclosure. Amman, Jordan: Wael Publishing House.

MEEK, G. K., Roberts, C. B., \& Gray, S. J. (2015) Factors influencing voluntary annual report disclosures by US, UK and continental European multinational corporations. Journal of International Business Studies, 26(3), 555-572.

Soliman, M. (2013). Firm characteristics and the extent of voluntary disclosure: the case of Egypt. 
Zarb, B. J. (2015). A Comparative Study of Voluntary Accounting Disclosures between Us and non-US Airline Companies. International Journal of Business, Accounting, \& Finance, 9(2).

\section{Copyrights}

Copyright for this article is retained by the author(s), with first publication rights granted to the journal.

This is an open-access article distributed under the terms and conditions of the Creative Commons Attribution license (http://creativecommons.org/licenses/by/4.0/). 